\title{
Special section - Ecological responses of arthropods to volcanism
}

The explosive eruption of the PuyehueCordón Caulle (PCC) volcanic complex on June 4th 2011 changed substantially the physiognomy of landscapes in northwestern Patagonia (Argentina). The ash fall resulting from this powerful eruption blanketed several million hectares, and prevailing westerly winds during and after the event generated steep ashfall gradients (Gaitán et al. 2011) (Fig. 1) with important effects on spatial heterogeneity. Several research groups conducting ongoing research projects in northern Patagonia envisaged the spatial heterogeneity generated by the ash fall as a natural experiment that offered a unique opportunity to evaluate ecological effects of these unpredictable and extreme events.

This special section reflects results of the workshop "Ashes and Arthropods" held at Laboratorio Ecotono, Bariloche in December of 2012 aimed at sharing conclusions about the structural and functional responses to volcanism of the arthropod fauna populations and communities and related impacts on ecosystem functioning. A particularly challenging goal of the workshop was to attempt to draw generalizations on effects among distinct arthropod taxa, guilds and

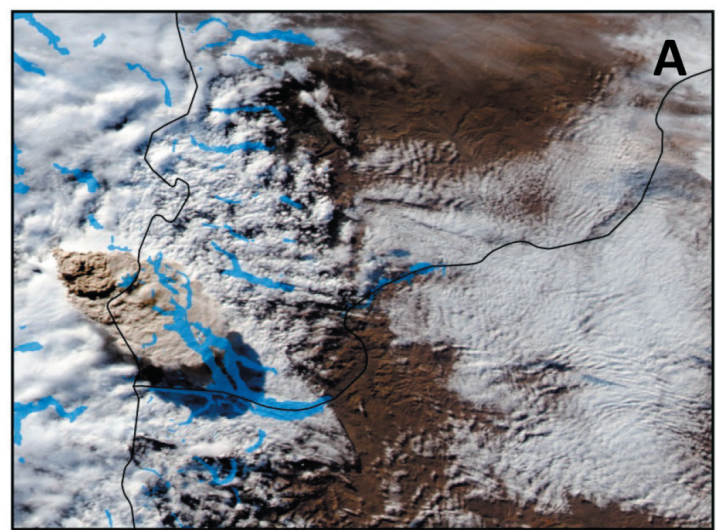

environments, from studies assessed at different spatial and temporal scales, and using a diverse array of conceptual and methodological approaches.

Contributions to this special section are from participants of that workshop plus some additional invitations. Briefly, the section starts with an exhaustive literature revision on volcanism effects on arthropods. Elizalde's review (pg. 3) reveals the importance of habitat modification, food availability reduction and cuticle abrasion as the most important effects. Interestingly, however these factors seem to vary in relative importance depending on the type and intensities of the disturbances derived from the eruption and the differential susceptibility of taxa. Buteler et al. (pg. 17) shows that, under controlled laboratory conditions, ashes from the PCC complex induced mortality on adult individuals, thus confirming the high potential of volcanic ash as an inert insecticide powder that could be used to control plague species.

Nonetheless, in spite of the important individual-level effects, the response in structural and functional components of local arthropod assemblages in natural

Figure 1. MODIS Aqua image taken on June 4th 2011, immediately after initial explosive eruption of the PuyehueCordón Caulle volcanic complex. The ash-pumicite cloud some $14 \mathrm{~km}$ high dipersed ejecta of decreasing granulometry with increasing distance from the crater (ocre tones) initially towards the SE direction (A). During the subsequent days and months fine ashes continued to be ejected (light gray tones) as a hundreds of km- long plume variably oriented towards the E, NE and SE. For instance, on June 132011 MODIS Terra imagery showed a c. $800 \mathrm{~km}$-long 3-4 km-high plume oriented eastwards (B) (Satellite data from MODIS Rapid Response Team at NASA GSFC).

Figura 1. Imagen MODIS Aqua tomada el 4 de junio de 2011, inmediatamente después de la erupción explosiva inicial del complejo volcánico Puyehue-Cordón Caulle. La nube de ceniza de unos $14 \mathrm{~km}$ de altura dispersa eyecciones de graunulometría decreciente al aumentar la distancia desde el cráter (tonos ocres), con dirección sudeste (A). Durante los días y meses posteriores continuó la expulsión de cenizas finas (tonos gris claro) a lo largo de cientos de kilómetros y en orientación variable hacia el este, noreste y sudeste. Por ejemplo, el 13 de junio de 2011 MODIS Terra mostró una c. $800 \mathrm{~km}$ de largo 3-4 km alta pluma orientada hacia el este (B) (datos satelitales de MODIS Equipo de Respuesta Rápida de la NASA GSFC). 
environments remains far more complex and system -specific. The ash deposits influenced little the structuring of both epigaeic ants and beetles assemblages. Pirk's study (pg. 23) shows reduction in ant abundance following the eruption while species richness and composition change remarkably little, Ruggiero \& Werenkraut (pg 31) show that ground beetle assemblages developing along altitudinal gradients retained similar abundance patterns both before and after the eruption although the post-eruptive shape of the abundance-elevation patterns somewhat differed across mountains receiving different ash deposit amounts .

In contrast to this apparent compositional resistance, some ecosystem functions may become disrupted if key species are affected. Morales et al. (pg. 42) found a strong, lasting disruption in plant-pollination interactions in relation to volcanism-related population collapses in key bumblebee species and general impoverishment of pollinator assemblages. Similarly, Chaneton et al. (pg. 51) found a widespread disruption of canopy-herbivore interactions in Nothofagus pumilio forests. Monitoring folivory rates over a 10-year span including the volcanic event led the authors to conclude that volcanic ash deposition events act as broad-spectrum insecticide recurrently releasing trees from chronic herbivory.

Studies performed in aquatic environments broadened the picture for a better understanding of the effects of ash deposit on arthropods. An exploratory analysis by Llallement et al. (pg. 64) in three mountain streams located at different distances from the volcano, showed important negative effects of ash benthic macroinvertebrates abundance, possibly related both to hydrological changes provoked by the large amounts of sediments as well as due to changes in intrinsic water quality to these organisms. Balseiro et al. (pg. 75) showed even higher complexity of effects of suspended ashes on planctonic invertebrates acting at different scales, from subcellular, individual, population to ecosystem levels. While suspended ashes affected positively the phytoplankton, possibly through shading and reduced photo inhibition, zooplankton species were temporarily negatively affected due to reduced filtering efficiency.

As a whole, the studies published in this special section suggest a number of issues that deserve attention in the attempt to understand the response of local arthropod communities to the disturbances derived from volcanic eruptions. First, although volcanic ash has the property of being a potent insecticide under laboratory conditions, these effects do not necessarily translate into important alterations in the local communities thus suggesting some degree of resistance, especially in communities that normally deal with previously deposited ashes such as epigeic organisms and/or those that have adaptations for digging. Flying organisms or organisms feeding on aerial structures may have suffered from the damaging action of ashes. Alternatively, ashes may have disrupted life cycles of taxa that overwinter (eruption occurred in winter) on the ground (e.g. ground-pupating insects). Aquatic invertebrates seem to have far more complex responses because ashes can sharply modify environmental parameters (light, hydrology) as well as feeding metabolisms and behavior. Because these effects vary by trophic level, highly complex and less predictable outcomes are expected in these systems. Finally, key ecosystem functions are generally played by a key a few species, thus disruption and recovery of the function is possibly related to how key actors are affected by these events. Long-term monitoring programs are and will be increasingly necessary to evaluate impacts of future events and to assess the recovery of populations and communities as well as the resilience of ecosystem to these events.

Acknowledgements: We thank especially Gabriela Pirk, Luciana Elizalde, Marina Arbetman and Victoria Werenkraut for their willing to organize the workshop, and also appreciate the predisposition of all contributing authors to publish good quality research in this special section.

\section{REFERENCES}

Gaitán, JJ, Ayesa, JA, Umaña, F, Raffo, F, Bran DB. 2011. Cartografía del área afectada por cenizas volcánicas en las provincias de Río Negro y Neuquén. Documentos INTA EEA Bariloche http:/ /inta.gob.ar/documentos/ cartografia-del-area-afectada-por-cenizas-volcanicas-enlas-provincias-de-rio-negro-y-neuquen.

\section{Adriana Ruggiero \& Thomas Kitzberger}

Laboratorio Ecotono - Universidad Nacional del Comahue (INIBIOMA-CONICET). Bariloche, Argentina 